\title{
The Type I Versus Type II Agency Conflict on Earnings Management
}

\author{
Yavida Nurim $\bowtie$, Sunardi, Rini Raharti \\ Faculty of Economics, Janabadra University, Yogyakarta, Indonesia
}

\section{Info Article}

History Article:

Received Januari 2017

Approved Februari 2017

Published Maret 2017

\section{Keywords:}

Corporate Governance; Earnings

Management; Ownership Concen-

tration; Reputation Quality; Type

I and II Agency Conflict.

\begin{abstract}
This study aims to detect the background of earnings management behavior in which it shows the tendency of type I or II agency conflict. The high ownership concentration of firms in Indonesia leads type II agency conflict, but the good corporate governance formulation assumes conflict between management and shareholders. This study uses published data in IDX from 2009-2014. The result reveals that reputation quality has negative significant correlation to earnings management behaviors, but corporate governance quality has insignificant correlation to earnings management, except percentage of independent commissioner board in moderate level. It has implication that management faces type II agency conflict. The majority may monitor management directly, so the finding reveals that independent commissioner board's function is not optimum as part of corporate governance mechanism. According to the evidence, corporate governance formulation, especially in Indonesia, should be needed for reducing earnings management on type II tendency.
\end{abstract}

\section{Konflik Keagenan Tipe I Versus Tipe II pada Manajemen \\ Laba}

\begin{abstract}
Abstrak
Penelitian ini bertujuan mendeteksi latar belakang perilaku managemen laba pada perusahaan di Indonesia, sehingga diketahui kecenderungan tipe konflik 1 ataukah 2 yang melatar belakangi konflik keagenan. Perusahaan di Indonesia merupakan perusahaan dengan kepemilikan terkonsentrasi dan hal itu mendorong terjadinya konflik keagenan tipe 2. Padahal rumusan tatakelola mengasumsikan kepemilikan menyebar atau terjadi konflik keagenan tipe 1 pada perusahaan tersebut. Penelitian ini menggunakan data yang dipublikasikan pada IDX dari tahun 2009-2014. Hasil mengungkapkan bahwa kualitas reputasi berpengaruh negative signifikan terhadap managemen laba, kualitas tata kelola perusahaan memiliki berpengaruh tidak signifikan terhadap manajemen laba, sehingga managemen menghadapi tipe konflik 2. Pemegang saham mayoritas dapat mengawasi managemen secara langsung, sehingga peranan dewan komisaris independen tidak optimum dalam mekansima tatakelola. Oleh sebab itu, perlu formulasi tatakelola yang dapat menurunkan tipe konflik keagenan tersebut.
\end{abstract}

JEL Classification: G3, G32 
Yavida Nurim, et al. / The Type I Versus Type II Agency Conflict on...

\section{INTRODUCTION}

There are two possibilities types of agency conflicts that depending on ownership setting. The type I agency conflict assumes that management takes benefit from shareholders, because agency conflict could happen in dispersed ownership. However, type II agency conflict assumes that majority shareholder expropriates minority shareholders, because this agency conflict type could happen in concentrated ownership. According to both characteristics, asymmetric information also depends on the conflict in which the management's objective is serving for.

However, corporate governance's formulation has an objective to reduce management behavior to act in self-interest. As the statement of Aguilera and Crespi-Cladera (2016), the objective of corporate governance mechanism design mitigates the conflict between manager and shareholders, so the design is on widely owned firm context.

This formulation assumes the dispersed ownership in company, such as the separation between ownership and control, and it leads to the type I agency problem in which conflict between management and shareholders. Bar-Yosef and Prencipe (2013) reveal that corporate governance quality does not have association with earnings management in Italia in where firm with high ownership concentration. Dominant shareholder has strong influence to CEO or commissioner board, thus investors consider the effect of directly monitoring from dominant shareholder.

Haw et al. (2011) also reveal that majority shareholders take benefit through private control privilege in concentrated ownership setting. As an implication, earnings management behavior by management has possibility of different objective that depends on agency conflict setting.

Dainelli et al. (2013) have revealed that the annual report as signal mechanism for reducing conflict between insiders and investors. The more profiTable firms encourage to pub- lish the more informative signal, such as growth perspectives, environmental and social performance indicators. This study also uses Italian sample that representing type II agency conflict.

According to the findings about implication of concentrated ownership, the purpose of this study is to provide empirical evidence in which agency conflict type may lead management to do earnings management in Indonesia. The ownership characteristic in Indonesia is also similar in the ownership characteristic in Italia, thus earnings management behavior may tend to behave majority minority conflict. This study uses reputation quality for representing type II agency conflict.

This study uses sample from IDX from 2009-2014. The proxy of corporate governance quality is percentage of independent commissioner board, number of commissioner board meeting, and number of audit committee meeting. Then the proxy of reputation quality is auditor quality and membership of Jakarta Islamic Index (JII) and LQ 45 as social performance indicators. Listyaningsih and Krishnamurti (2015) use JII as a proxy for ethical investment in which moral issue is considered.

The examination reveals that percentage of independent commissioner board has insignificant correlation to earnings manipulation. This result does not support the finding of Zgarni et al. (2014) and Busirin et al. (2015) that independent commissioner board can reduce earnings manipulation behavior, because independent commissioner board ability in monitoring the earnings process will dismiss the ineffective director team and will encourage management allocate to resources into optimum return (Schipper, 1989 ; Xie et al., 2003). The higher proportion of independent board shows the higher chance to avoid selfish behavior by management (Manzaneque et al., 2016).

However, commissioner board meeting and audit committee meeting have insignificant correlation to earnings management. Then, the insignificant correlation between percentage of independent commissioner board and earnings management shows that the controlling and 
monitoring mechanism is not optimum. Therefore, corporate governance quality does not affect to earnings manipulation.

The examination also reveals that audit quality has negative significant correlation to earnings management and membership of JII and LQ 45 also has negative significant correlation to earnings manipulation. It indicates that reputation quality encourage management to enhance higher quality of financial reporting by reducing earnings management behavior.

This finding shows that sample company face type 2 agency conflict. It implies that corporate governance mechanism considers to reduce majority and minority conflict.

This study extends Bar-Yosef and Prencipe (2013) and Madhani (2016) through considering association between reputation quality and earnings management as type II agency conflict. The reputation quality will show management's effort in maintaining the minority's trust. Management needs to guarantee that there is not majority expropriation to minority.

This study also extends the statement of Aguilera and Crespi-Cladera (2016) that corporate governance mechanism design considers dispersed owned firm context. As an implication, investors may not consider earnings management risk in high ownership concentration setting because of monitoring directly from the majority. Thus this study contributes to corporate governance formulation, especially in high ownership concentration setting, such as Indonesia, because majority can monitor management directly.

The corporate governance mechanism should be needed for reducing earnings management in type II tendency. The corporate governance does not longer emphasize overcome the conflict between management and shareholder or on agency type I. Therefore, corporate governance formulation must consider the ownership structure as stated by Rose (2016) that corporate governance formulation needs to review over time because each criteria of formulation could not be equally important.
The structure of this article is as follows: the section "hypotheses development" describes the literature review, and "method" section describes data and sample, variables, and model. Then the "result" section describes the statistic descriptive and hypothesis examination. At last, the "result and discussion" section describes implication, limitation and future research opportunity.

\section{Hypothesis Development \\ Type I Agency Conflict and Corporate Gover- nance Quality}

Studies about agency conflict typically assume that the conflict exists between management as agent and shareholders as principal. Jensen and Meckling (1976) state that management encourages to maximize his/ her interest and it against shareholder's interest.

This conflict actually happens in countries (exp. US) that corporate owner or shareholders as capital owner separate from management as capital manager. As an effect, according to achieving self-interest, management manipulates firm's performance through financial reporting. In one side, shareholders judge management's performance based on firm's financial statement and in other side, shareholders could not directly monitor management's behavior.

Lafond and Roychowdhury (2008) argue that alignment between manager and shareholders has negative correlation to conservatism demand. Lafond and Roychowdhury (2008) use asymmetric timelines of earnings for measuring conservatism. This study reveals that the accounting conservatism has negative association with director ownership such number of stock owned director. It implies that alignment as such director ownership encourages decreasing manager self-interest.

Cheng et al. (2016) also support the finding about separation between manager and shareholder affect in achieving management self-interest. Cheng et al. (2016) reveal that check and balances mechanism in CEO team could reduce real earnings management. CEO in corporate has subordinates and the team will 
Yavida Nurim, et al. / The Type I Versus Type II Agency Conflict on...

decide financial decision, therefore, many kinds of self-interest between members of CEO team, such as desire to be next CEO or to have more career encourage for caring future cash flow, can motivate to monitor other CEO.

The findings of Lafond and Roychowdhury (2008) and Cheng et al. (2016) show that separation between agent as equity manager and principle as equity owner could encourage management maximizing his/ her self-interest. The separation will encourage management decreasing conservatism and increasing real earnings manipulation (Lafond \& Roychowdhury, 2008; Cheng et al., 2016). Therefore, in dispersed ownership setting, it needs a mechanism that can control and monitor management for behaving as shareholder interest. At least, thus mechanism can improve alignment between manager and shareholder.

Fama and Jensen (1983) state that corporate governance encourages interest alignment between management and shareholders. Corporate governance mechanism has an objective to reduce management behavior such maximizing his/ her self-interest. The mechanism provides infrastructure, such as commissioner board and audit committee, for controlling and monitoring management's activities.

The controlling and monitoring activities enhance firm value through optimum profit. The infrastructure is also expected to encourage management publishing high quality of financial reporting. At least, the mechanism could reduce the aggressive earnings management.

The one of strategy to increase quality financial reporting is to reduce the aggressive earnings management behavior and it brings consequence higher firm value. As a consequence of public trust, Bar-Yosef and Prencipe (2013) reveal that corporate governance mechanism has a positive significance to market liquidity. González and Muñoz (2016) also find the same results.

Darrat et al. (2014) suggest that attributes of corporate governance, such as board characteristics, have more explanatory power than profitability or accounting ratio for predic- ting bankruptcy. Liang et al. (2016) also suggest that bankruptcy prediction using corporate governance index and financial ratio better than using financial ratio alone.

Contradiction finding by Rose (2016) that corporate governance comply has insignificant relationship with firm performance. Rose (2016) states that corporate governance formulation needs to review over time because each criteria of formulation could not be equally important.

\section{The Independent Commissioner Board}

The number of independent commissioner board is the one of the firm's monitoring and controlling infrastructure. Xie et al. (2003) state that commissioner board has right to dismiss the ineffective director team. Therefore, commissioner board can encourage management to allocate resources into optimum return (Schipper, 1989).

Rostami et al. (2016) reveal that independent of commissioner board has a positive significant relationship with ROA and stock return. This finding contradict with Zabri et al. (2016). However, the finding of Nisasmara and Musdholifah (2016) and Manzaneque et al. (2016) supports the finding of Rostami et al. (2016).

Nisasmara and Musdholifah (2016) also reveal that independent commissioner size has positive correlation to firm value. The higher proportion of independent board the lower likelihood bankruptcy because the number of independent board shows the chance to avoid selfish behavior by management (Manzaneque et al., 2016).

The statements suggest that monitoring and controlling from independent of commissioner board enhance good performance for corporate. The controlling and monitoring mechanism also should achieve more reliable financial reporting, because management does not have more possibilities to have moral hazard or adverse selection in financial reporting.

Madhani (2016) states that size of commissioner board has significant effect on firms' corporate governance implementation and 
also disclosure practice. Then, the higher independent commissioner board enhances lower earnings manipulation behavior (Zgarni et al., 2014).

Independent commissioner board can reduce earnings manipulation behavior because the board has ability pressure from inside firm and monitor earnings process (Busirin et al., 2015). Kamalluarifin (2016) states that independent commissioner board can interrupt management to publish unreliable financial statement. Moreover, the interruption can delay the publication. Therefore, Kamalluarifin (2016) reveals that independent commissioner board size has negative correlation with timeliness financial reporting.

Moreover, commissioner member should behave independent in accordance with majority and minority conflict. As an example, the top 100 Malaysian public listed companies have lower minority expropriation in which the companies have higher number of independence board on audit committee (Hamid et al., 2016).

The findings show that independent commissioner board as monitoring and controlling mechanism has important role in increasing reliability of financial reporting. Therefore, this hypothesis is stated as below:

H1a: Percentage of independent commissioner board has negative correlation to earnings management.

\section{The Commissioner Board Meeting}

The higher independent commissioner board in a corporate has possibility to enhance higher opportunity to influence managerial decision. However, the influence should be performed in formal meeting, because the recorded meeting has authentic proof about the effectiveness of controlling or monitoring and also the progress of meeting between commissioner board and management if the meeting has objective to get a certain solution.

Zgarni et al. (2014) reveal that number of commissioner board has negative association with sales manipulation. Zgarni et al. (2014) argue that more frequently meeting between commissioner board and management will achieve more ability to prevent manipulation.

However, Zgarni et al. (2014) also reveal that the meeting does not have correlation with discretionary expenses. Zgarni et al. (2014) use real earnings management for manipulation detection. Nisasmara and Musdholifah (2016) also reveal that the commissioner board meeting does not have correlation to firm value. It means that the commissioner board meeting could not influence investors. However, the meeting can become a way to reduce the aggressiveness of management behavior.

Based on the important role of meeting between commissioner board and director in type 1 agency conflict, the hypothesis is stated as below:

H1b: Number of meeting between commissioner board and director has negative correlation to earnings management.

\section{The Audit Committee Meeting}

Audit committee is also the part of internal corporate governance mechanism, because commissioner board delegates the day to day control and monitor activities. Thus, audit committee has important role to reduce information asymmetry between management and shareholders and also to encourage management to publish more reliable financial reporting.

The study about the role of audit committee has revealed that audit committee members who have adequate accounting and finance knowledge can monitor earnings management activities (Chen \& Zhang, 2014). That study also reveals that the role of audit committee team will be more effective in reducing earnings management behavior if the team should be chaired by an independent commissioner board.

However, Chen and Zhang (2014) find that the existence of audit committee does not have significant influence in mitigating earnings management. The finding implies that characteristic of audit committee has important role in effectiveness of corporate governance. Audit committee should have formal mechanism, such as meeting, to maintain the effective communi- 
cation with management. The formal meeting provides authentic proof about the controlling or monitoring activities whereby commissioner board decision based on it.

Based on the important role of meeting between audit committee and director in type 1 agency conflict, the hypothesis is stated as below:

H1c: Number of meeting between audit committee and director has negative correlation to earnings management.

\section{The Type II Agency Conflict and Reputation Quality}

Studies about agency conflict also have grown that conflict also happens between majority shareholder and minority shareholder because of concentrated ownership setting. In Indonesia, majority shareholders have privilege to choose the corporate organ, such as commissioner board, independent auditor, through Shareholder General Meeting (RUPS). Then, commissioner board will choose board of director and audit committee. In many cases, majority chooses board of director, so it is common that board of directors has family relationship with majority shareholders. It implies that director board's interest may align with majority's interest.

In concentrated ownership setting, there is possible that commissioner board and board of director give their loyalty to majority shareholder that has a significant power to hire or dismiss them. It shows that majority could monitor and control the management's activities directly. It indicates that concentrated ownership reduces management behaving self-interest maximization, but as consequence, the majority is suspected possibility of getting advantages from private information.

Therefore, Rostami et al. (2016) reveal that concentrated ownership has a positive significant correlation to ROA. However, direct controlling and monitoring encourage majority taking advantages private information, then as an effect, concentrated ownership has a negative significant correlation to stock return (Rosta- mi et al., 2016). Bar-Yosef and Prencipe (2013) also state that higher concentrated ownership has higher bid-ask spread and lower volume trade. The positive relationship between concentrated ownership and bid-ask spread shows less extensive accounting disclosure or information asymmetry. However, trade volume indicates willingness to transact, so concentrated ownership is suspected as the existence information asymmetry.

Dainelli et al. (2013) state that relationship conflict between insiders and investors need more signaling mechanism such as informative performance that indicates incremental informative power for investors. The informative signal could be stated in financial performance or non-financial indicators, such as growth perspectives, environmental and social performance indicators. Dainelli et al. (2013) also state that in less regulated system, more profiTable firms encourage to provide more information as market signal.

\section{The Auditor Quality}

Auditor quality reflects on ability or independent of external corporate governance mechanism to encourage management behaving in shareholders' interest. Otherwise, it also shows a goods signal of management's commitment for reporting reliable financial statement.

Audit independence has negative correlation to earnings management (Noor et al., 2015). However, the finding of Haw et al. (2011) and Persakis and Iatridis (2016) require the investor protection for optimizing the audit quality mechanism in corporate governance implementation.

Haw et al. (2011) states that big $\mathrm{N}$ only has important role in high investor protection country. It implies that monitoring of big $\mathrm{N}$ auditor will be effective in high investor protection country. Persakis and Iatridis (2016) also support the finding of Haw et al. (2011) that audit quality is affected by institutional factors, such as investor protection, legal enforcement. The higher audit quality, the higher earnings quality in country with high investor protection. 
However, Bell et al. (2015) state that tenure determines the audit quality, because in first year audit has lower audit quality than the second and third year audit. It implies that association between audit quality and investor protection should be considered in earnings quality debate.

In Korea, big $\mathrm{N}$ auditor will reduce stock price crash risk for IFRS adopting companies (Lim et al., 2016). Big $\mathrm{N}$ auditor has important role in a firm adopting IFRS because investors invest on more transparent companies.

Ismail et al. (2015) also reveal that big $\mathrm{N}$ auditor has negative significant relationship to earnings management. This study uses sample from publicly companies in Malaysia. The findings imply that decision to choose big $\mathrm{N}$ auditors has meaning that majority shareholder may increase his/ her corporate reputation.

The findings state that auditor quality has important role for increasing the reputation of companies through the audit quality. Based on the important role of auditor quality in type 2 agency conflict, the hypothesis is stated as below: $\mathrm{H} 2 \mathrm{a}$ : Auditor quality has negative correlation to earnings management.

\section{The Jakarta Islamic Index and LQ 45}

Jakarta Islamic Index (JII) contains of company stocks that their operational comply with Islamic Rules, and LQ 45 index contains of company stocks that their market capitalization $10 \%$ highest and transaction 5\% highest in Indonesia Stock Exchange.

The both of index indicate the environmental and social performance indicators, so according to Dainelli et al. (2013), the membership could become incremental informative power for investors, especially firms that have conflict with investors. Listyaningsih and Krishnamurti (2015) also use JII as a proxy for ethical investment in which moral issue is considered.

Based on the important role of JII and LQ 45 membership in type 2 agency conflict, the hypothesis is stated as below.

H2b: Membership of Jakarta Islamic Index and

LQ 45 has negative correlation to earnings management.

\section{METHOD}

\section{Data and Sample}

This study uses secondary data published by Indonesia Stock Exchange (IDX). The secondary data are used to examine corporate governance quality, reputation quality, and earnings management. The corporate governance quality uses commissioner board, commissioner board meeting, and audit committee meeting data and the reputation quality uses auditor and Jakarta Islamic Index and LQ 45 data. Then earnings management uses financial data that are detailed in earnings management formula.

This research sample is firms that listed in IDX from 2009-2014 and sample should be as criteria below:(1) Firms are not part of finance and bank sector; (2) Firms have to fulfill the examination formula; (3) Firms do not have loss earnings; (4) Firms have to publish three consecutive financial reporting.

\section{Variable Definition}

This research uses variables as below: (1) The earning management variable as dependent variable that is measured by discretionary accrual level based on Modified Jones formula (see formula as below); (2) The corporate governance quality variables as independent variables. The variable uses proxies, namely percentage of independent commissioner board, number of commissioner board meeting, and number of audit committee meeting. The percentage of independent commissioner board is measured by independent member divided by non-independent member of commissioner board. The meeting is measured by number of meeting divided by number of commissioner board and also for audit committee is number of meeting divided by number of commissioner board.

(3) The reputation variables as independent variable and it uses proxies, namely auditor quality and membership of Jakarta Islamic Index (JII) and LQ 45. Auditor quality is measured by big $\mathrm{N}(1)$ and non-big $\mathrm{N}(0)$, then also for JII and LQ 45 membership (1) and vice 
Yavida Nurim, et al. / The Type I Versus Type II Agency Conflict on...

versa $(0)$; (4) The control variables that used in this study are return on investment and age (month). Company may attract investor or creditor by doing income increasing, so higher good performance has higher discretionary accrual. Company may behave conservative such as doing income decreasing, especially company that has survived in long period.

This detail below is the formula for counting discretionary accrual as Modified Jones Model.

$\mathrm{TAC}_{\mathrm{it}} / \mathrm{A}_{\mathrm{it}-1}=\alpha_{1}\left(1 / \mathrm{A}_{\mathrm{it}-1}\right)+\alpha_{2}\left(\Delta \mathrm{REV}_{\mathrm{it}}-\Delta\right.$ $\left.\mathrm{REC}_{\mathrm{it}}\right) / \mathrm{A}_{\mathrm{it}-1}+\alpha_{3}\left(\mathrm{PPE}_{\mathrm{it}} / \mathrm{A}_{\mathrm{it}-1}\right)+\ddot{v}_{\mathrm{it}}$

Note:

TAC = Total accruals (net incomecash flow from operations)

$\Delta \mathrm{REV}=$ Change of total revenue

$\Delta$ REV $=$ Change of total account receivable

$\Delta \mathrm{PPE} \quad=$ Change of net value of equipment and building

$\ddot{v} \quad=$ Residual

All variables are scaled by total assets $A_{i t-1}$.

\section{Research Model}

The examination model for this study is depicted as below:

$\mathrm{DAC}=\alpha 1+\alpha 2 \mathrm{AQ}+\alpha 3 \mathrm{MJII} \& 45+\alpha 4 \mathrm{PICB}+$ $\alpha 5 \mathrm{MCB}+\alpha 6 \mathrm{MAC}+\alpha 7 \mathrm{ROA}+\alpha 8 \mathrm{AGE}+\varepsilon$

Note:

$$
\begin{array}{ll}
\mathrm{DAC} & =\text { discretionary accrual } \\
\mathrm{AQ} & =\text { auditor quality; big N (1) } \\
& \text { and non-big N (0) } \\
\text { MJII\&45 } & =\text { JII and LQ45 membership; }
\end{array}
$$

Table 1: The Characteristics of Sample member (1) and non-member (0)

$\mathrm{PICB}=$ percentage of independent commissioner board; independent divided by non-independent commissioner board.

$\mathrm{MCB}=$ commissioner board meeting; number of meeting divided by number of commissioner board.

MAC = audit committee meeting; number of meeting divided by number of audit committee

ROA = return on assets

Age = firms age (month)

\section{RESULT AND DISCUSSION}

\section{Statistic Descriptive}

This study uses 466 companies as sample and representing 2,645 firm-year observations for the period 2009-2014. The sample has characterized as depicted in Table number 1 . Total companies from 2009-2014 is 3,123. This study excludes finance and bank companies because those companies are implemented different corporate governance formula. The total of sample from 2009-2014 after excluding finance and bank is 2,645 (see Table 1).

As Table 1, this study also eliminates sample that does not fulfill the examination formula and there are 2.053 firms that have been eliminated from sample. Then finally, firms with loss earnings also are eliminated as 126 companies and the sample total is 466 firms. Although this study states that sample from 2009-2014, but actually sample becomes decreasing with

\begin{tabular}{ll}
\hline Characteristic of Sample & The Number of Sample \\
\hline Companies from 2009-2014 & 3,123 \\
Excluded: finance and bank & 478 \\
Total companies from 2009-2014 & 2,645 \\
Exclude: Incomplete data & 2,053 \\
\hline & 592 \\
\hline Exclude: losses & 126 \\
Total of sample & 466 \\
\hline
\end{tabular}


that criteria. Therefore, this study only makes limitation with three consecutive financial reporting for firm sample.

Statistic descriptive for research variable is detailed in Table 2. Firm sample behaves income increasing and it can be known from discretionary accrual mean as 0.076 with 0.39 as standard deviation. Firm sample does not tend to use big $\mathrm{N}$ auditor, so mean of auditor quality is 0.37 and 0.484 for standard deviation.

The Table 2 shows that most firm sample also is not member of JII and LQ 45, so mean is 0.12 and standard deviation is 0.326 . For 466 firm samples, the mean of independent commissioner board percentage is 0.692 and standard deviation is 0.5075 .

The Table 2 shows that most of firm sample has independent commissioner board more at least as same as the non-independent commissioner board. In Table 2 also shows that the mean of commissioner board meeting variable and audit committee meeting variable is 3.312 and 7.925 respectively and also standard deviation is 3.97 and 6.68. It means that the mean of commissioner board meeting is three times a year, but the audit committee meeting variable is almost eight times a year. The mean of control variables is 0.09 and 219.83 respectively ROA and age, and the standard deviation is 0.079 and 92.72 for ROA and age, respectively.

This study examines normality data by Kolmogonov-Smirnov and the result states the significance level at 0.306 that it is higher than 0.05 , so the sample data has normal distributi- on. The value of Durbin Watson (DW) is 0.819 in which $(4-0.79)>d U(2.251)$, so there is no negative autocorrelation, but $\mathrm{dL}=0.78$ and DW between $\mathrm{dL}$ and $\mathrm{dU}$ or no conclusion about positive autocorrelation. There is no multi-collinearity between independent variable, because VIF value $=1.047$ is lower than 10 and higher than 1 . The result of heterocedastic shows that significancy level lower than 0.05 , so the variance data is not significant.

\section{Hypothesis Result}

Hypothesis number 1 from "a" to " $c$ " is to examine the corporate governance quality, because it indicates the effort of firm to reduce type I agency conflict. Hypothesis number 2 from "a" to " $b$ " is to examine the reputation quality that it will show the effort management to reduce type II agency conflict. However, hypothesis number 1a also can be for showing the effectiveness corporate governance for reducing type II agency conflict.

Hypothesis number 1a states that percentage of independent commissioner board has negative correlation to earnings management. This hypothesis has objective to show the effectiveness of commissioner board control could decrease majority and minority conflict.

The result shows that percentage of independent commissioner board has insignificant correlation with discretionary accrual (see Table 3). This result does not support the finding of Zgarni et al. (2014) and Busirin et al. (2015) that independent commissioner board can

Table 2: The Mean and Standard Deviation of Variables

\begin{tabular}{lll}
\hline Variables & Mean & Standard Deviation \\
\hline Discretionary Accrual (DAC) & 0.076 & 0.39 \\
Auditor Quality (AQ) & 0.37 & 0.484 \\
Member JII andLQ45 (MJII\&45) & 0.12 & 0.326 \\
$\begin{array}{l}\text { Percentage of Independent Commissioner } \\
\text { (PICB) }\end{array}$ & 0.692 & 0.5075 \\
Meeting of Commissioner Board (MCB) & & \\
Meeting of Audit Committee (MAC) & 3.312 & 3.9779 \\
ROA & 7.925 & 6.686 \\
Age & 0.09 & 0.079 \\
& 219.83 & 92.723 \\
\hline
\end{tabular}


reduce earnings manipulation behavior, because of independent commissioner board ability in monitoring the earnings process.

The insignificant correlation shows that independent commissioner board does not have optimal role in corporate governance mechanism. The result contradicts the prior research, such as Schipper (1989) and Xie et al. (2003) state the independent commissioner board can dismiss the ineffective director team and can encourage management allocate to resources into optimum return. The result also contradicts with Rostami et al. (2016) and Nisasmara and Musdholifah (2016) that argue that independent of commissioner board gets positive response from investor.

For illustration, the finding of Rostami et al. (2016) that independent commissioner board has a positive significant relationship with return on asset (ROA) and stock return. Rostami et al. (2016) also reveal that independent commissioner size has positive correlation to firm value.

Manzaneque et al. (2016) state that the higher proportion of independent board shows the higher chance to avoid selfish behavior by management. The statements suggest that the power of shareholders as high motivation for management to achieve more reliable financial reporting. Management does not have more possibilities to have moral hazard or adverse selection in financial reporting.
However, the result of this study does not support the hypothesis 1a, so monitoring and controlling from independent of commissioner board do not enhance good performance implementation for corporate.

Hypothesis number $1 \mathrm{~b}$ states that number of meeting between commissioner board and director has negative correlation with earnings management. The result states that the number of commissioner board meeting has insignificant correlation to discretionary accrual (see Table 3).

The finding supports the finding of Zgarni et al. (2014) and Nisasmara and Musdholifah (2016). Zgarni et al. (2014) state that the number of commissioner board meeting has insignificant relationship with discretionary expenses. Nisasmara and Musdholifah (2016) also reveal that the commissioner board meeting does not have correlation to firm value. It means that the commissioner board meeting could not influence investors, because the meeting cannot reduce the aggressiveness of management behavior in manipulation.

Hypothesis number 1c states that number of meeting between audit committee and director has negative correlation to earnings management. The result states that the number of audit committee meeting has insignificant correlation with discretionary accrual (see Table 3 ).

This finding support the finding of Chen and Zhang (2014), the existence of audit com-

Table 3: The Hypotheses Result Examination

\begin{tabular}{lll}
\hline Variables & Coefficient & t \\
\hline Percentage of Independent Commissioner Board (PICB) & -0.066 & $-1.859^{*}$ \\
Meeting of Commissioner Board (MCB) & -0.004 & -0.809 \\
Meeting of Audit Committee (MAC) & 0.001 & 0.473 \\
Auditor Quality (AQ) & -0.120 & $-.250^{* * *}$ \\
Member JII and LQ45 (MJII\&45) & -0.134 & $-2.368^{* *}$ \\
ROA & 0.662 & $2.283^{* * *}$ \\
Age & -0.001 & $-.109^{* * *}$ \\
\hline
\end{tabular}

Notes:

*) $\operatorname{sig}<10 \%$

**) sig $<5 \%$

***) $\operatorname{sig}<1 \%$ 
mittee does not have significant influence in mitigating earnings management. The formal mechanism of audit committee, such as meeting, to maintain the effective communication with management does not have significant role for controlling or monitoring activities in which independent commissioner board may control and monitor directly.

The both of meeting mechanisms have objective to reduce type 1 agency conflict. However, results reveal that meeting of commissioner board and audit committee does not have significant correlation to discretionary accrual. It implies that the corporate governance mechanism is not optimum in implementation because majority shareholders could control and monitor management directly.

The three examinations indicate the corporate governance implementation in sample company for reducing type 1 agency conflict. This study reveals that $\mathrm{H} 1 \mathrm{a}$, namely independent commissioner board has insignificant relationship to earnings management. The study also shows that the meeting number, such as commissioner board and audit committee ( $\mathrm{H} 1 \mathrm{~b}$ and $\mathrm{H} 1 \mathrm{c})$, has insignificant relationship to earnings management. This finding indicates that corporate governance mechanism does not have enough important role in reducing the aggressiveness management behavior in manipulation.

Then, this study will examine the second hypothesis ( $\mathrm{H} 2 \mathrm{a}$ and $\mathrm{H} 2 \mathrm{~b})$ that indicates the type 2 agency conflict. The both hypothesis show the reputation quality for reducing conflict between majority and minority shareholders. Hypothesis number 2 a states that auditor quality has negative correlation to earnings management. The result shows that auditor quality has negative significant correlation to discretionary accrual. It shows that auditor quality can encourage management to reduce the aggressive earnings management behavior.

The finding supports Noor et al. (2015) that audit independence has negative correlation to earnings management. It also supports Bell et al. (2015) state that tenure determines the audit quality and the finding in Korea that big $\mathrm{N}$ auditor will reduce stock price crash risk for IFRS adopting companies (Lim et al., 2016). Ismail et al. (2015) also reveal that big $\mathrm{N}$ auditor has negative significant relationship to earnings management. This study uses sample from publicly companies in Malaysia. The findings imply that decision to choose big $\mathrm{N}$ auditors has meaning that majority shareholder may increase his/ her corporate reputation.

However, the finding does not support Haw (2011) and Persakis et al. (2016) that audit quality requires the investor protection mechanism for optimizing corporate governance implementation. For illustration that Haw (2011) and Persakis et al. (2016) state that big $\mathrm{N}$ is only affected by institutional factors, such as investor protection, legal enforcement. The higher audit quality, the higher earnings quality in country with high investor protection.

The result also shows that management takes benefit from the reputation of auditor as signal about management's commitment for reporting reliable financial statement. It implies that auditor quality may become a good signal for investors whereby management shows their commitment to maintain investor's interest through more perceived honorable reputation than non big N.

Hypothesis number $2 b$ is to support the result of $\mathrm{H} 2 \mathrm{a}$ in which the hypothesis examines the reputation quality. The result states that membership of Jakarta Islamic Index and LQ 45 has negative correlation to earnings management. The examination result $2 \mathrm{~b}$ supports the $2 \mathrm{a}$ and it means that the sample face type 2 agency conflict.

According to the result of $\mathrm{H} 2 \mathrm{~b}$, management needs more signaling mechanism for reducing majority and minority conflict. Listyaningsih and Krishnamurti (2015) also use JII as a proxy for ethical investment in which moral issue is considered.

The index indicates the reputation of comply with Islamic Rules and of capitalization 10\% highest Indonesia Stock Exchange. The both of index indicate company match with the 
environmental and social performance indicators. According to Dainelli et al. (2013), the membership could become incremental informative power for investors, especially firms that have conflict with investors. Result of control variables shows that ROA has positive significant correlation to discretionary accrual. However, age has negative significant correlation with discretionary accrual.

Higher company's performance tends to have higher discretionary accrual. The good performance may be part of management strategy to enhance higher reputation. It also supported by the second result of control variable that longer sustainability of company tends to have lower discretionary accrual. It implies that companies in which has shorter sustainability needs enhance good reputation through increasing discretionary accrual. As consequence, the company also needs increasing discretionary accrual for enhance good reputation. Therefore, companies which good performance has positive correlation to earnings management in which companies have shorter sustainability.

\section{CONCLUSIONAND RECOMMENDATION}

This study has aim to detect the tendency of management doing earnings management as whether management face type I or Type II agency conflict. Studies of earnings management cannot abandon ownership setting, because ownership characteristic indicates whether or not the shareholder has ability for directly controlling or monitoring.

In concentrated ownership setting, shareholders could monitor management directly, however the condition is opposite in dispersed ownership. Therefore, in widely ownership, the conflict may involve majority shareholder and minority shareholder. This research is important to be performed because mostly ownership characteristic in Indonesia is concentrated in family ownership.

For the objective of the type I agency conflict, this research uses corporate governance implementation quality. Then for the ob- jective of type II agency conflict detection, this research uses reputation quality. The proxy of corporate governance implementation quality is percentage of independent commissioner board, number of commissioner board meeting, and number of audit committee meeting, and then the proxy of reputation quality is auditor quality (big $\mathrm{N}$ or non big $\mathrm{N}$ ) and membership of Jakarta Islamic Index and LQ 45. This study uses sample from IDX from 2009-2014 excluding bank and finance sector.

The first three hypotheses (H1a to 1c) has objective to detect the type 1 agency conflict in which percentage of independent commissioner board (H1a), commissioner board meeting ( $\mathrm{H} 1 \mathrm{~b})$ and audit committee meeting (H1c) correlate with earnings management. Then, the second two hypotheses ( $\mathrm{H} 2 \mathrm{a}$ to $2 \mathrm{~b}$ ) has objective to detect the type 2 agency conflict in which auditor quality $(\mathrm{H} 2 \mathrm{a})$ and membership of Jakarta Islamic Index and LQ 45 (H2b) correlate to earnings management.

The result of first hypothesis (H1a) shows that percentage of independent commissioner board has insignificant correlation to discretionary accrual. This result does not support the finding of Zgarni et al. (2014) and Busirin el al. (2015) that independent commissioner board can reduce earnings manipulation behavior. Zgarni et al. (2014) and Busirin el al. (2015) state that independent commissioner board have ability in monitoring the earnings process.

The insignificant correlation also shows that the result contradicts with Schipper (1989) and Xie et al. (2003) that commissioner board can dismiss the ineffective director team and it can encourage management allocate to resources into optimum return. The result also does not support Manzaneque et al., (2016) that the higher proportion of independent commissioner board shows the higher chance to avoid selfish behavior by management.

The result of second hypothesis ( $\mathrm{H} 1 \mathrm{~b})$ shows that the number of meeting between commissioner board and director has insignificant correlation to discretionary accrual. The finding supports the finding of Zgarni et 
al. (2014) and Nisasmara and Musdholifah (2016). Zgarni et al. (2014) state that number of commissioner board meeting has insignificant relationship to discretionary expenses. Nisasmara and Musdholifah (2016) also reveal that the commissioner board meeting does not have correlation to firm value. It means that the commissioner board meeting could not become a way to reduce the aggressiveness of management behavior.

The result of the third hypothesis (H1c) also states that the number of audit committee meeting has insignificant correlation to discretionary accrual. This result supports the prior finding that the existence of audit committee does not have significant influence in mitigating earnings management (Chen \& Zhang, 2014). The formal mechanism of audit committee, such as meeting, to maintain the effective communication with management does not have significant role for controlling or monitoring activities in which independent commissioner board may control and monitor directly.

Based on the study, percentage of independent commissioner board only has moderate negative correlation to earnings management. It implies that the effect of controlling and monitoring by independent commissioner board does not have optimal role in corporate governance mechanism.

The argument is also supported the examination result of $\mathrm{H} 1 \mathrm{~b}$ in which insignificant correlation between independent commissioner board meeting and discretionary accrual and of $\mathrm{H} 1 \mathrm{c}$ in which insignificant correlation between audit committee meeting and discretionary accrual.

Therefore, the both of controlling and monitoring mechanisms in which commissioner board characteristic and audit committee meeting does not have significant correlation to discretionary accrual. In other word, percentage of independent commissioner board and audit committee meeting can not reduce the aggressiveness earnings management behavior.

According to the result, the sample of company may face type 2 agency conflict in which majority and minority conflict as consequence of concentrated ownership in Indonesia. Thus reason is based on the argument that majority shareholder may control and monitor management directly, so corporate governance mechanism is not optimum in implementation. The majority shareholders could control and monitor management directly through majority's privilege in RUPS in which management, auditor, or commissioner board are choose.

The second hypothesis has objective to serve an empirical evidence for type 2 agency conflict. According to the objective, the second hypothesis uses reputation quality through auditor reputation $(\mathrm{H} 2 \mathrm{a})$ and membership of Jakarta Islamic Index and LQ45 (H2b). The examination result of $\mathrm{H} 2 \mathrm{a}$ shows that auditor quality has negative significant correlation to discretionary accrual. It shows that auditor quality can encourage management to reduce the aggressive earnings management behavior.

The finding supports Noor et al. (2015) that audit independence has negative correlation to earnings management. It also supports Bell et al. (2015) state that tenure determines the audit quality and the finding in Korea that big 4 auditor will reduce stock price crash risk for IFRS adopting companies (Lim et al., 2016).

Ismail et al. (2015) also reveal that big N auditor has negative significant relationship to earnings management. This study uses sample from publicly companies in Malaysia. The findings imply that decision to choose big $\mathrm{N}$ auditors has meaning that majority shareholder may increase his/ her corporate reputation.

However, the finding does not support Haw (2011) and Persakis et al. (2016) that audit quality requires the investor protection mechanism for optimizing corporate governance implementation. For illustration that Haw (2011) and Persakis et al. (2016) state that big $\mathrm{N}$ is only affected by institutional factors, such as investor protection, legal enforcement. The higher audit quality, the higher earnings quality in country with high investor protection.

The result also shows that management takes benefit from the reputation of auditor as 
signal about management's commitment for reporting reliable financial statement. It implies that auditor quality may become a good signal for investors whereby management shows their commitment to maintain investor's interest through more perceived honorable reputation than non big $\mathrm{N}$.

The examination result of $\mathrm{H} 2 \mathrm{~b}$ reveals that membership of JII and LQ 45 have negative significant correlation to earnings management. The membership could encourage management to reduce the aggressiveness in earnings management behavior. This finding shows that management face type II agency conflict, because earnings management behavior has objective to enhance good signal for investor.

This finding implies that corporate governance mechanism need to consider type 2 agency conflict in which majority and minority conflict. According this conflict, controlling and monitoring have objective to reduce expropriation behavior from majority to minority. Therefore, the role of independent commissioner board is necessary to be optimum. The alternative mechanism is to reduce the role of RUPS in choosing auditor.

This study has two limitations and it correlate with data characteristic. Then, based on the limitation, this study offers two possibility of topic as opportunity future research. The first limitation, this study does not use ultimate ownership data because in Indonesia firms do not publish ultimate shareholders. The future research can use ultimate shareholders for moderating variable, so direct monitoring can be examined to show the influence of majority shareholders for internal organ activities include corporate governance mechanism.

The second limitation, this research also does not use corporate governance index for counting corporate governance quality. This index requires ability researcher to access unpublished data, such as meeting notes, that it will complete the meeting data between management and commissioner board and audit committee. The future research considers survey method for achieving more complete meeting data.
This research does not trace how long director involves in that company. The involvement will show the possibility the type agency conflict, because study has difficulty to trace family relationship between director and shareholder. The future research should consider the involvement period of director board as moderating variable.

\section{REFERENCES}

Aguilera, R. V \& Crespi-Cladera, R. 2016. Global corporate governance: On the relevance of firms' ownership structure. Journal of World Business. 51 (1): 50-57.

Bar-Yosef, S \& Prencipe, A. 2013. The Impact of Corporate Governance and Earnings Management on Stock Market Liquidity in a Highly Concentrated Ownership Capital Market. Journal of Accounting, Auditing \& Finance. 28 (3): 293-316.

Bell, T. B., Causholli, M \& Knechel, W. R. 2015. Audit Firm Tenure, Non-Audit Services, and Internal Assessments of Audit Quality. Journal of Accounting Research. 53 (3): 461-509.

Busirin, M. F., Azmi, N. A \& Zakaria, N. B. 2015. How Effective is Board Independence to the Monitoring of Earnings Manipulation?. Procedia Economics and Finance. 31: 462-469.

Cheng, Q., Lee, J \& Shevlin, T. 2016. Internal Governance and Real Earnings Management. The Accounting Review. 91 (4): 1051-1085.

Chen, J. J \& Zhang, H. 2014. The Impact of the Corporate Governance Code on Earnings Management - Evidence from Chinese Listed Companies. European Financial Management. 20 (3): 596-632.

Dainelli, F., Bini, L \& Giunta, F., 2013. Signaling strategies in annual reports: Evidence from the disclosure of performance indicators. Advances in Accounting. 29 (2): 267-277.

Darrat, A. F., Gray, S., Park, J. C \& Wu, Y. 2014. Corporate Governance and Bankruptcy Risk. Journal of Accounting, Auditing \& Finance. 31(2): 163-202.

Fama, E. F \& Jensen, M. C. 1983. Separation of Ownership and Control. Journal of Law and Economics. 26 (2): 301-325.

Hamid, M. A., Ting, I. W. K \& Kweh, Q. L. 2016. The Relationship between Corporate Gover- 
nance and Expropriation of Minority Shareholders' Interests. Procedia Economics and Finance. 35: 99-106.

Haw, I.-M., Ho, S. S. M \& Li, A. Y. 2011. Corporate Governance and Earnings Management by Classification Shifting. Contemporary Accounting Research. 28 (2): 517-553.

Ismail, N. I., Zakaria, N. B \& Sata, F. H. A. 2015. Auditors Roles Towards the Practice of Earnings Manipulation among the Malaysian Public Firms. Procedia Economics and Finance. 28: 145-150.

Jensen, M. C \& Meckling, W. H. 1976. Theory of The Firm: Managerial Behavior, Agency Costs and Ownership Structure. Journal of Financial Economics. 3 (4): 305-360.

Kamalluarifin, W. F. S. W. 2016. The Influence of Corporate Governance and Firm Characteristics on the Timeliness of Corporate Internet Reporting By Top 95 Companies in Malaysia. Procedia Economics and Finance. 35: 156-165.

Lafond, R \& Roychowdhury, S. 2008. Managerial Ownership and Accounting Conservatism. Journal of Accounting Research. 46 (1): 101-135.

Liang, D., Lu, C. C., Tsai, C. F \& Shih, G. A. 2016. Financial ratios and corporate governance indicators in bankruptcy prediction: A comprehensive Study. European Journal of Operational Research. 252 (2): 561-572.

Lim, H., Kang, S. K \& Kim, H. 2016. Auditor Quality, IFRS Adoption, and Stock Price Crash Risk: Korean Evidence. Emerging Markets Finance and Trade. 52 (9): 2100-2114.

Listyaningsih, E. \& Krishnamurti, C. 2015. How Performance of Jakarta Islamic Index (JII) Stocks Relative to Other Stocks. Jurnal Dinamika Manajemen. 6 (2): 145-164.

Madhani, P. M. 2016. The Impact of Legal and Regulatory Environment: A Study of Corporate Governance and Disclosure Practices of Firm Listed on Bombay Stock Exchange. The IUP Journal of Corporate Governnace. 15 (2): 7-36.

Manzaneque, M., Priego, A. M \& Merino, E. 2016. Corporate governance effect on financial distress likelihood: Evidence from Spain. Revista de Contabilidad. 19 (1): 111-121.
Noor, N. F.M., Sanusia, Z. M., Heang, L. T., Iskandar, T. M \& Isa, Y. M. 2015. Fraud Motives and Opportunities Factors on Earnings Manipulations. Procedia Economics and Finance. 28: 126-135.

Nisasmara, P. W \& Musdholifah. 2016. Cash Holding, Good Corporate Governnace and Firm Value. Jurnal Dinamika Manajemen. 7(2): 120-131.

Persakis, A \& Iatridis, G. E. 2016. Audit quality, Investor Protection and Earnings Management During The Financial Crisis of 2008: An International Perspective. Journal of International Financial Markets, Institutions and Money. 4: 73-101.

Rose, C. 2016. Firm performance and comply or explain disclosure in corporate governance. $E u$ ropean Management Journal. 34 (3): 202-222.

Rostami, S., Rostami, Z \& Kohansal, S. 2016. The Effect of Corporate Governance Components on Return on Assets and Stock Return of Companies Listed in Tehran Stock Exchange. Procedia Economics and Finance. 36: 137-146.

Schipper, K. 1989. Commentary on Earnings Management. Accounting Horizon, Volume December. 3: 91-102.

González, N. U \& Muñoz, F. J.C. 2016. Do investors react to corporate governance news? An empirical analysis for the Spanish market. BRQ Business Research Quartely. 19 (1): 13-25.

Xie, B., Davidson III, W. N \& Dadalt, P. J. 2003. Earnings Management and Corporate Governance: The Role of Board and The Audit Committee. Journal of Corporate Finance. 9 (3): 295 - 316.

Zabri, S. M., Ahmad, K \& Wah, K. K. 2016. Corporate Governance Practices and Firm Performance: Evidence from Top 100 Public Listed Companies in Malaysia. Procedia Economics and Finance. 35: 287-296.

Zgarni, I., Halioui, K \& Zehri, F. 2014. Do The Characteristics of Board of Directors Constrain Real Earnings Management in Emerging Markets? Evidence from The Tunisian Context. The IUP Journal of Accounting Research \& Audit Practices. 8 (1): 46 - 61. 